\title{
The Presumption of Innocence: A Deflationary Account
}

\author{
Federico Picinali*
}

\begin{abstract}
The presumption of innocence is unanimously considered a fundamental requirement for criminal justice. This notwithstanding, the meaning of the presumption is hotly disputed in the legal scholarship. The article contributes to this debate, advancing a novel theory of the meaning as well as of the justification of the presumption of innocence. It assesses critically the components of the presumption that are discussed and defended in the literature; and it shows that the meaning of the presumption should be unloaded of most of these components. The upshot is a markedly deflationary account, according to which the presumption of innocence consists exclusively of a rule on the allocation of the burden of proof. This rule is justified by appealing to the principle of inertia in argumentation, rather than - as it generally occurs - to the value of protecting the innocent from conviction.
\end{abstract}

\section{Introduction}

The presumption of innocence is unanimously viewed as a fundamental requirement for criminal justice. In other words, it is considered a norm of such importance that, if we were to relinquish it, we could not see ourselves as doing justice in the criminal law domain. The norm has a common-law pedigree, ${ }^{1}$ it is enshrined in art. 6(2) of the European Convention on Human Rights (ECHR), and in other international law instruments. $^{2}$

Given this state of affairs, one may be surprised to discover that in the legal scholarship there is much disagreement concerning the meaning of the presumption. To be sure, this problem is not unique to the presumption of innocence. Other procedural norms present a similar puzzle: they are generally hailed as fundamental for criminal justice, whilst their meaning - and often also their justification - are the subject of unrelenting dispute. Clear examples of this phenomenon are the privilege

\footnotetext{
* Law Department, London School of Economics and Political Science. The author is grateful to Paul Roberts and Antony Duff for their valuable comments on an earlier draft. A previous version of this article was presented at the Gerald Gordon Seminar, University of Glasgow, on 11 June 2019. The author thanks the participants for their feedback.

${ }^{1}$ The classic reference is Woolmington v DPP [1935] AC 462 (HL). For a recent analysis of this case see Lindsay Farmer, 'Innocence, the Burden of Proof and Fairness in the Criminal Trial: Revisiting Woolmington v DPP (1935)', in John D. Jackson and Sarah J. Summers (eds.) Obstacles to Fairness in Criminal Proceedings: Individual Rights and Institutional Reforms (Hart 2018) at 57.

${ }^{2}$ See art. 11(1) of the Universal Declaration of Human Rights and art. 48 of the Charter of Fundamental Rights of the European Union.
} 
against self-incrimination ${ }^{3}$ and the reasonable doubt standard. ${ }^{4}$ In the case of the presumption of innocence, though, the puzzle is of a particularly troubling nature. Many seem to hold that in the fabric of the criminal process the presumption is a thread with special structural importance: a deeper thread than the privilege against selfincrimination and a thicker thread than the reasonable doubt standard. Indeed, it is sometimes argued that the presumption of innocence justifies - or contributes to the justification of - the privilege. ${ }^{5}$ And - as will be discussed later - it is often claimed that the reasonable doubt standard is one of the components of the presumption.

The goal of this article is to advance a novel normative theory of the meaning and of the justification of the presumption of innocence. As regards the former, the article shows that the presumption of innocence should be understood as encompassing exclusively a rule on the allocation of the burden of proof. All academic accounts of the meaning of the presumption of which the author is aware are richer than that defended here. They generally consider the rule on the allocation of the burden of proof as the core element of the presumption, but also read into the presumption one or more additional components. The article engages with the academic literature analysing each of these further components in turn, and showing that the meaning of the presumption should be unloaded of all of them. The deflationary theory defended here differs also from the common law understanding of the presumption. In England and Wales, courts have traditionally conceived of the presumption of innocence - also referred to as the 'golden thread' of the criminal law ${ }^{6}$ - as including the reasonable doubt standard. ${ }^{7}$ This construal is rejected in the article. Finally, the theory of the

\footnotetext{
${ }^{3}$ On the complexities of the justification and of the meaning of the privilege, see the unparalleled Mike Redmayne, 'Rethinking the Privilege Against Self-Incrimination' (2007) 27 Oxford Journal of Legal Studies 209.

${ }^{4}$ On the meaning and the justification of the reasonable doubt standard see, respectively Federico Picinali, 'Two Meanings of "Reasonableness": Dispelling the "Floating" Reasonable Doubt' (2013) 76 Modern Law Review 845 and Federico Picinali, 'Can the Reasonable Doubt Standard Be Justified? A Reconstructed Dialogue' (2018) 31 Canadian Journal of Law and Jurisprudence 365.

${ }^{5}$ See Stefan Trechsel, Human Rights in Criminal Proceedings (OUP 2005), at 166, 348, writing that reliance on the presumption of innocence provides 'a fully satisfactory justification for the existence of the privilege' and referencing ECtHR decisions that draw a similar link between the two norms. Cf. Ian Dennis, 'Instrumental Protection, Human Right or Functional Necessity? Reassessing the Privilege Against Self-Incrimination' (1995) 54 Cambridge Law Journal 342, at 353-356; Redmayne, supra note 3, at 218-219.

${ }^{6}$ This is the influential metaphor used in Woolmington, supra note 1, stating at 481-482: 'Throughout the web of the English Criminal Law one golden thread is always to be seen, that it is the duty of the prosecution to prove the prisoner's guilt subject ... to the defence of insanity and subject also to any statutory exception. If, at the end of and on the whole of the case, there is a reasonable doubt, created by the evidence given by either the prosecution or the prisoner ... the prosecution has not made out the case and the prisoner is entitled to an acquittal. No matter what the charge or where the trial, the principle that the prosecution must prove the guilt of the prisoner is part of the common law of England and no attempt to whittle it down can be entertained'.

${ }^{7}$ See Woolmington, supra note 1 (consider, especially, the passage reported supra note 6 and, more generally, pages 481 and 482), Andrew Stumer, The Presumption of Innocence: Evidential and Human Rights Perspectives' (Hart 2010), at 1-8, Paul Roberts and Adrian Zuckerman, Criminal Evidence (OUP 2010), ch.
} 
meaning of the presumption advanced here differs from the interpretation of art. $6(2)$ ECHR given by the European Court of Human Rights (ECtHR). The main divergence lies in the fact that the ECtHR interprets the presumption as including a rule on how the suspect/accused should be treated, ${ }^{8}$ whereas this article argues against such a view.

Whilst the meaning of the presumption is hotly debated, its justification is generally agreed upon. In a nutshell, the popular argument is that the presumption is justified by the need to protect the innocent from the improper use of state power and, in particular, from conviction. ${ }^{9}$ The article advances an alternative justification of the presumption. It argues that the rule on the allocation of the burden of proof - which, as stated earlier, is seen to exhaust the meaning of the presumption - is justified by a requirement of rationality, the principle of inertia in argumentation. This principle has been briefly theorised in the academic literature, ${ }^{10}$ but it has never been adequately fleshed out or discussed with reference to the presumption of innocence. The article undertakes these tasks.

The plan of the work is as follows. Section 2 addresses possible components of the presumption of innocence that concern the process of proving facts at trial. These components are: a rule concerning the allocation of the burden of proof, the standard of proof, and a rule defining the point of departure for the fact finder's task. The rule on the allocation of the burden of proof is the obvious starting point for the analysis

6, and John D. Jackson and Sarah J. Summers, The Internationalisation of Criminal Evidence: Beyond the Common Law and Civil Law Traditions (CUP 2012), at 200-204. Whilst this article does not focus on the US system, it is worth pointing out that the theory of the meaning of the presumption of innocence defended here differs markedly from the conception of the presumption traditionally endorsed by US courts. In Coffin v. US, the case through which the presumption of innocence formally entered US law (on this point see Kenneth Pennington, 'Innocent until Proven Guilty: The Origins of a Legal Maxim' (2003) 63 Jurist 106, at 108), the Supreme Court defined the presumption of innocence as a legal presumption, and elaborated on this definition by adding that the presumption 'is evidence in favor of the accused' (see Coffin v US, 156 US 432 (1895), at 460). Also, in Bell v Wolfish (441 U.S. 520 (1979)) the Supreme Court argued that the presumption of innocence includes a rule to the effect that the fact finder should decide the issue of guilt only on the basis of the evidence presented at trial. Finally, US courts have sometimes argued that the presumption of innocence is a logical implication of the reasonable doubt standard (see Larry Laudan, Truth, Error, and Criminal Law: An Essay in Legal Epistemology (CUP 2006), at 90-93). As will be seen, the theory defended in this article departs from all these views. To conclude this brief overview, consider that in continental systems such as the Italian, the presumption of innocence is traditionally understood as including a rule of treatment of the suspect/accused something that the paper denies. See Aldo Ghiara, 'Presunzione di Innocenza, Presunzione di 'Non Colpevolezza' e Formula Dubitativa, anche alla Luce degli Interventi della Corte Costituzionale' (1974) Rivista Italiana di Diritto e Procedura Penale 72.

${ }^{8}$ See Trechsel, supra note 5, at 163-164, 178-191. This and further points of disagreement between the theory of the presumption of innocence presented here and the ECtHR's are highlighted in the following sections. See, in particular, footnotes 58, 86, 94, and 99 and the accompanying text.

${ }^{9}$ See infra section 2.1.

${ }^{10}$ See Chaim Perelman \& Lucie Olbrechts-Tyteca, Traité de l'Argumentation: La Nouvelle Rhétorique, $2^{\text {nd }}$ edn (Brussels: Editions de l'Institut de Sociologie de l'Université Libre de Bruxelles, 1970), at 140-148 and Robert Alexy, A Theory of Legal Argumentation: The Theory of Rational Discourse as Theory of Legal Justification (Oxford: OUP, Ruth Adler and Neil MacCormick trans., 1989), at 171-173, 195-197. 
offered in this article, since it is the common denominator of virtually all existing accounts of the presumption and it is generally considered the presumption's core. None of the additional components enjoys as much support. Section 3, instead, addresses possible components of the presumption that concern the treatment of the suspect/accused. ${ }^{11}$ It considers whether the presumption of innocence includes a rule stating that the suspect/accused should be treated as an actually and/or a legally innocent person. Section 4 offers some concluding remarks.

One last introductory note. Whilst the normative theory of the presumption of innocence advanced here is elaborated with the English and Welsh system in mind, the reader will see that none of the arguments put forward in its support presupposes any feature that is specific to this system. The reach of the theory, therefore, may extend far beyond England and Wales. ${ }^{12}$

\section{Possible components of the presumption relating to the process of proof}

In this section, the article considers possible components of the presumption of innocence that concern the process of proving facts at trial. There is widespread consensus that the presumption contributes to regulating this process. There is, however, some disagreement about the nature of the contribution. Does the presumption include a rule on the allocation of the burden of proof? Does it include a standard of proof? Does it include a rule imposing on the fact finder a particular cognitive attitude to be adopted at the start of the trial, or imposing some other kind of point of departure? This section addresses these questions in turn.

\subsection{A rule allocating the burden of proof}

\footnotetext{
${ }^{11}$ Someone may object to the distinction drawn here between components pertaining to the process of proof and components concerning the treatment of the suspect/accused. They may argue that insofar as the former components define the trial that the suspect/accused is given, such components are also about the treatment of the suspect/accused. Should someone take this approach, the partition adopted here could still be maintained by referring to the components discussed in section 2 as those concerning the process of proof, and to the components discussed in section 3 as those not concerning such a process.

${ }^{12}$ In a characteristically perceptive and rigorous article, Paul Roberts argued 'that the best or most appropriate concept of the presumption of innocence depends on the purposes for which it is being deployed and the methods that are being used to investigate it...There are [he continues] no innocent concepts ..., because all conceptual definitions build in (implicit or explicit) preferences regarding the researcher's motivations and methods.' See Paul Roberts, 'Presumptuous or Pluralistic Presumptions of Innocence? Methodological Diagnosis towards Conceptual Reinvigoration', Synthese (2020) https://doi.org/10.1007/s11229-020-02606-2, at 2-3 (italics in the original). The author is sympathetic to Roberts' point, which seems to have much broader application than the debate on the presumption of innocence. And the author accepts Roberts' later invitation to spell out one's purpose and method: as clarified in the text, the purpose of this article is to advance a normative theory of the presumption of innocence as the most appropriate for the English and Welsh system; as it will become clear from reading the article, the principal method adopted here is conceptual analysis.
} 
It is generally accepted that the presumption of innocence is not a 'legal presumption of fact'. ${ }^{13}$ This phrase is used to refer to evidentiary devices that require or authorise the inference of a fact that would not, or could not, be inferred on the basis of the available evidence. For example, under section 76 of the Sexual Offences Act 2003, the fact finder is required to infer the complainant's lack of consent to a sexual act if it is proven that the defendant 'intentionally induced the complainant to consent ... by impersonating a person known personally to the complainant'. The presumption of innocence does not require or authorise any inference whatsoever. Instead, it imposes a particular conclusion of the fact finding process - i.e., an acquittal - for the case in which the prosecution has not succeeded in proving the defendant guilty to the satisfaction of the applicable standard. One may object that, in fact, the presumption demands that the fact finder infer innocence if, at the end of the trial, the prosecution has not proven guilt. It is mistaken, though, to conceptualise the presumption as treating innocence like the end point of an inference. The presumption, instead, posits innocence - and the enjoyment of rights connected to it - as the starting point or status quo, which the prosecution may alter only if it is successful in establishing guilt. Rather than demanding an inference of innocence, then, the presumption allocates to the prosecution the burden of proving guilt.

The rule according to which at trial the prosecution bears the burden of proving the defendant's criminal responsibility is generally recognised as the core component of the presumption of innocence. Besides being widely acknowledged in the literature, ${ }^{14}$ this rule has a solid basis in the conception of the presumption defended by the ECtHR ${ }^{15}$ and by the English and Welsh case law. ${ }^{16}$ It is generally justified by appealing to the need to protect the liberty, dignity, and reputation of the innocent, all values that would be undermined by a false conviction. Further related reasons that are often offered in support of the rule are the imbalance of resources between the prosecution

\footnotetext{
${ }^{13}$ See Roberts and Zuckerman, supra note 7, at 231, Roberts, supra note 12, at 21, Richard Glover, Murphy on Evidence (OUP 2015, 14 $4^{\text {th }}$ edition), at 738-739, and Roderick Munday, Cross and Tapper on Evidence (OUP 2018, $13^{\text {th }}$ edition), at 134-135. Cf. Pamela R. Ferguson, 'The Presumption of Innocence and Its Role in the Criminal Process' (2016) 27 Criminal Law Forum 131, at 135-137 and James B. Thayer, 'Presumption of innocence in Criminal Cases' (1897) 6 Yale Law Journal 185.

${ }^{14}$ See, among others, Andrew Ashworth, 'Four Threats to the Presumption of Innocence' (2006) 10 International Journal of Evidence and Proof 241, at 243; Roberts and Zuckerman, supra note 7, at 244; Stumer, supra note 7, at xxxviii; Antony Duff, 'Presuming Innocence' in Lucia Zedner and Julian V. Roberts (eds.) Principles and Values in Criminal Law and Criminal Justice (OUP 2012); Jackson and Summers, supra note 7, at 200; Liz Campbell, 'Criminal Labels, the European Convention on Human Rights and the Presumption of Innocence' (2013) 76 Modern Law Review 681, at 682-683; Ian Dennis, The Law of Evidence (Sweet and Maxwell 2013, Fifth Edition), at 445. This component of the presumption is also recognised by academics focusing on legal systems other than the English and Welsh, or on no system in particular. See P. J. Schwikkard, Presumption of Innocence (Juta and co. 1999), at 29; Laudan, supra note 7, at 93-96; Richard L. Lippke, Taming the Presumption of Innocence (OUP 2016), Ch. 4 and 5.

${ }^{15}$ See Trechsel, supra note 5, at 167-174.

${ }^{16}$ See Woolmington, supra note 1 , where the rule according to which the burden of proving guilt is on the prosecution is seen as a component of the 'golden thread' of English criminal law - the other component being the standard of proof beyond a reasonable doubt.
} 
and the defence, and the consideration that fact finding is fallible and that - because of the costs of a conviction for the innocent - the risk of error should be allocated unevenly between the parties, so that most of it is borne by the prosecution. ${ }^{17}$ In a nutshell, then, the mainstream justification of the rule allocating to the prosecution the burden of proof is centred around the value of protecting the innocent from conviction. ${ }^{18}$

In a recent work, Richard Lippke has provided an alternative justification for this rule, and for the presumption of innocence in general. ${ }^{19}$ As will become clear later in the article, Lippke's conception of the presumption is richer than a rule on the allocation of the burden of proof. It involves an articulated 'proof structure', of which this rule is an essential building block. In Lippke's view, the components of the presumption are justified on the grounds that each contributes to ensure - and to assure the polity - that when a fellow citizen is convicted, this is done justifiably. Given the significant level of intrusion into the rights of liberty, privacy and autonomy represented by punishment, we should want a conviction to occur only in the presence of a justification for it. The presumption of innocence exists to ensure that this is the case. For Lippke, then, the presumption's raison d'être is not so much the sheltering of the innocent from conviction, as it is the protection of the rights that would be curtailed by a conviction, protection that should be afforded whether the bearer of these rights is innocent or guilty. ${ }^{20}$ Lippke's 'moral assurance account ${ }^{21}$ of the presumption centres around the rights of the defendant, not just the rights of the innocent defendant.

Whilst this article agrees that the presumption of innocence includes a rule allocating to the prosecution the burden of proving criminal responsibility, it disagrees with how this component is normally justified. To clarify, it is recognised here that the value of protecting the innocent and, more generally, the defendant's rights are reasons for having this rule. There is, however, a reason that takes priority over these

\footnotetext{
${ }^{17}$ See Ashworth, supra note 14, at 251; Stumer, supra note 7, at 28-37; Roberts and Zuckerman, supra note 7, at 244-247; Campbell, supra note 14, at 683; Dennis, supra note 14, at 445-446. For a discussion of the argument on the imbalance of resources and of further practical considerations in favour of allocating the burden of proof to the prosecution, see Paul Roberts, 'Taking the Burden of Proof Seriously' [1995] Criminal Law Review, at 785-788.

${ }^{18}$ In a recent article, Andrew Roberts has argued that the presumption of innocence includes a 'right to the most accurate procedures. The presumption - he writes - requires the state to do as much as it can to protect individuals from wrongful conviction.' See Andrew Roberts, 'The Frailties of Human Memory and the Accused's Right to Accurate Procedures' [2019] Criminal Law Review 916. This interpretation is defended by considering that the most accurate procedures would provide protection from conviction to the innocent, and that the value of protecting the innocent is at the heart of the presumption. Even assuming that this last consideration is correct, Roberts does not do enough to show that the protection afforded to the innocent by the presumption should be maximal (powerful arguments against maximal epistemic protection can be found in much of Larry Laudan's legal scholarship, and should be engaged with), and to explain how a practicable criminal justice system could provide such a protection

${ }^{19}$ See Lippke, supra note 14, Ch. 5.

${ }^{20}$ See id Ch. 5 and, in particular, 110-113.

${ }^{21}$ See id at 110 .
} 
and that alone is sufficient to justify the rule. This reason is the principle of inertia in argumentation.

\subsubsection{The principle of inertia in argumentation}

The principle of inertia in argumentation has been theorised, first, by Chaim Perelman and Lucie Olbrechts-Tyteca and, later, by Robert Alexy. Their accounts of the principle, though, are rather terse and discuss its role in legal argumentation generally. Whilst what follows builds on these accounts, it develops them significantly. This is done in order to clarify the connection between the principle and rationality and, especially, to explain the functioning of the principle in the specific context of the criminal process.

According to the principle of inertia, in the absence of sufficient reasons to the contrary, the status quo must be preserved. ${ }^{22}$ The phrase 'status quo' is used here to refer to any state of affairs that has been previously agreed upon by the parties involved in an argumentative exchange. It may be a shared plan of action or a shared view of the world. The principle implies that if a party wants the status quo to change, she has to give the others sufficient reasons for such a change; ${ }^{23}$ she has to discharge a burden of proof. Consider, for example, a group of friends who have agreed to meet at someone's house and watch a particular movie. If a member of the group has a change of mind and wants the group to watch a different movie, she will have to advance sufficient reasons in order to persuade the rest of the group to change the communal plan. Absent such reasons, the plan should not change. ${ }^{24}$

The relevant status quo for the purposes of the argumentation taking place at trial is the defendant's enjoyment of rights, ${ }^{25}$ including the right to liberty, to privacy, to

${ }^{22}$ See Perelman \& Olbrechts-Tyteca, supra note 10, at 140-148. At 142 the authors write: 'Le plus souvent ... l'orateur ne peut tabler, pour ses présomptions, que sur l'inertie psychique et sociale, qui, dans les conscionces et dans les sociétés, fait pendant à l'inertie en physique. On peut présumer, jusqu'à prevue du contraire, que l'attitude adoptée antérieurement - opinion exprimée, conduit préférée - se continuera dans l'avenir ... Le changement, par contre, doit être justifié ; une decision, une fois prise, ne peut être renversée que pour des raisons suffisantes.' See also Alexy, supra note 10, at 171-173, 195-197. At 195 Alexy writes: '[the] principle of inertia stipulates that a view or practice which has once been accepted should not be abandoned without some reason'. As Alexy points out, the principle of inertia 'has the character of a rule allocating the ... burden of proof' (ibid. at 171-172. A similar claim is made at 268). According to Perelman, Olbrechts-Tyteca, and Alexy, the principle of inertia performs further roles in addition to allocating the burden of proof in an argumentative exchange. 'It underlies the appeal to precedent and to accepted norms in both legal science and ethics' and, more generally, 'it makes argument actually possible' by allowing for presuppositions without which no argumentation could begin (ibid, at 172. See also Perelman \& Olbrechts-Tyteca, supra note 10, at 144). Perelman and OlbrechtsTyteca also view the principle as the foundation of the 'rule of justice', according to which like cases should be treated alike (ibid., at 294).

${ }^{23}$ Of course, a party might not succeed in providing sufficient reasons for the change that she desires, but the reasons provided might be sufficient for a less radical change. It still remains the case that whatever the change of the status quo, it cannot take place in the absence of sufficient reasons for it. ${ }^{24}$ Of course, some factors that are external to the argumentation (e.g., the fact that the DVD of the chosen movie breaks) may bring the group ultimately to change the plan, but these are beside the point.

${ }^{25}$ Of course, by the time of the trial some of the defendant's rights may have already been restricted in particular, the defendant may have been remanded in custody. In light of this, it may be more precise 
property. ${ }^{26}$ To clarify, this status quo is not a cognitive attitude about the innocence of the defendant. It is not an epistemic status quo - a view of the world. It is, instead, a practical status quo - a plan of action - consisting in affording the defendant, as a member of the polity, the enjoyment of the rights to which all innocent members are entitled. This enjoyment of rights has been agreed upon by the polity through the appropriate institutional mechanisms, legislation above all. A conviction - with the accompanying sentence - constitutes an infringement of some of the defendant's rights, thus a change in the status quo. Therefore, the prosecution - who argues for such a change - has the burden to prove to the polity that there are sufficient reasons for it. This is done by producing evidence showing that the defendant is responsible for a crime. ${ }^{27}$ The presumption of innocence enforces the principle of inertia in the criminal trial. It reminds us that the defendant's unfettered enjoyment of the prerogatives of the innocent is the relevant status quo, the state of affairs that our polity has agreed upon. Implementing the principle, the presumption provides that anyone arguing for a change of this status quo has to justify it by proving that the defendant is responsible for a crime. In the absence of such evidence, the status quo must be preserved. ${ }^{28}$

As the above examples indicate, the principle of inertia concerns the form of the argumentation, not its content. It allocates the burden of proof, but it says nothing about what the status quo is or how it might change. Moreover, it says nothing about what constitute sufficient reasons for a given change. ${ }^{29}$ These matters define the argumentative context and may vary significantly from one context to another. The principle of inertia, instead, invariably applies in each context. Indeed, the principle is operative both in the case of the group of friends planning to watch a movie and in the case of the criminal trial; but the relevant status quo, the change of it being sought, and the assessment of sufficiency of the reasons for such a change differ markedly in the two argumentative contexts. The previous paragraph identified the status quo and the proposed change thereof for the argumentative context of the criminal trial. ${ }^{30} \mathrm{As}$

to define the status quo at the start of the trial as that in which the defendant's rights are not limited by any measure requiring a conviction (e.g., punishment). This definition does not alter the argument to follow.

${ }^{26}$ Among these rights there may even be a 'right not to be punished', that is, not to be subject to hard treatment and censure. See Douglas Husak, Overcriminalization: The Limits of the Criminal Law (Oxford: OUP, 2008), at $92 \mathrm{ff}$.

${ }^{27}$ Section 2.1.2 infra clarifies what it means to show that the defendant is responsible for a crime.

${ }^{28}$ One might argue that the principle of inertia does not make any original contribution to the debate on the presumption of innocence since it replicates the honoured Roman maxim 'ei incumbit probatio qui dicit, non qui negat'. Whilst the author does not deny that the implications of this maxim for the criminal trial may be the same as that of the principle (discussed infra section 2.1.2), the two are not equivalent. If anything, the role of the principle is to justify a rule such as that stated in the maxim. The principle is not such a rule.

${ }^{29} \mathrm{Cf}$. Alexy, supra note 10, stating at 173 that the principle of inertia 'says nothing about when [the status quo] is to be doubted and about how the matter should be decided in cases of doubt'. Setting these criteria is left 'to the reasonableness of those participating in discussion'.

${ }^{30}$ Someone may envisage a criminal justice system including one or more intermediate verdicts between acquittal and conviction, each accompanied by a respective standard of proof and sanction. 
pointed out, the reasons for such a change are the incriminating evidence presented at trial. ${ }^{31}$ The assessment of sufficiency of these reasons, then, presupposes the identification of the facts that constitute criminal responsibility and of the standard of proof that needs satisfying in order to consider these facts established. Even if the principle of inertia itself is silent on these matters, the questions remain as to what are the facts that the prosecution must prove to obtain a change of the status quo and as to whether a standard of proof can nonetheless be read into the presumption of innocence. These two questions are addressed below, respectively in subsections 2.1.2 and 2.2.

Notice that respect for the principle of inertia can be regarded as a requirement of rationality in argumentation $-{ }^{32}$ at least if we assume the rationality of the parties involved. Rationality consists in the validity of reasoning, that is, in its 'formal correctness'. ${ }^{33}$ In other words, an instance of reasoning is rational insofar as its conclusion is correctly inferred from its premises, whether or not premises and conclusion are morally and epistemically sound. ${ }^{34}$ Imagine, for instance, that the legislator intends to minimise false acquittals and believes that making an extensive use of reverse burdens of proof is a means to achieve this goal. Given these premises,

Indeed, the author defended such a system in 'Do Theories of Punishment Necessarily Deliver a Binary System of Verdicts? An Exploratory Essay' (2018) 12 Criminal Law and Philosophy 555. In this system there would be more than one potential change of the status quo: the more radical the change, the more the evidence needed to justify it. The principle of inertia would still apply. Each change would require sufficient reasons, as indicated by the corresponding standard of proof. In the absence of sufficient reasons for any change, the status quo would be preserved. The bottom line is that the principle operates also in many-valued argumentative contexts, that is, in argumentative contexts in which decision-making is not binary.

${ }^{31}$ It might be argued that the reasons for criminalising conduct in the first place are among the reasons for the change in the status quo. These reasons too must be provided by the state, even though this happens at the legislative stage, not in the context of the trial. In this context, instead, reasons for criminalising are a given, in the sense that they don't need giving again. Hence, they are not part of the content of the argumentation taking place at trial; rather, they are a background factor that contributes to defining that argumentative context.

${ }^{32}$ This is how it is regarded by Alexy, supra note 10, who includes the principle in his 'theory of rational discourse'.

${ }^{33}$ See G. H. von Wright, 'Images of Science and Forms of Rationality' in G. H. von Wright, The Tree of Knowledge and Other Essays (Leiden: E. J. Brill, 1993), at 173.

${ }^{34}$ See von Wright, supra note 33, at 172, 173 (stating that '[a]n argument can be rational but its premisses and conclusions may be unreasonable'). See also the conceptions of rationality endorsed in Picinali, 'Two Meanings', supra note 4, at 855-856; W. M. Sibley, 'The Rational Versus the Reasonable' (1953) 62 The Philosophical Review 554, at 555-557; C. Perelman, The New Rhetoric and the Humanities: Essays on Rhetoric and its Applications (Dordrecht: D. Reidel Publishing Company, W. Kluback trans., 1979), at 117118; J. Rawls, Political Liberalism (New York: Columbia University Press, 1993), at 50, 51; and R. Alexy, 'The Reasonableness of Law' in G. Bongiovanni, G. Sartor, C. Valentini (eds) Reasonableness and Law (Dordrecht: Springer, 2009), at 5-7. 
it is rational for the legislator to decide to make such a use of reverse burdens. This decision, indeed, correctly follows from the premises. ${ }^{35}$

Now, if a group of rational individuals - that is, of individuals capable of rational reasoning - has agreed upon a plan of action or a view of the world, they will have done so because the reasons of which they are aware warrant an inference to that plan or view; in other words, because that plan or view is correctly inferred from the available reasons. For a change in the agreed-upon state of affairs - i.e., the status quo - to take place, the group must be made aware of sufficient reasons to disrupt the inference previously drawn. Failing this, the balance of available reasons continues to favour the status quo. Hence, rationality demands that the status quo be maintained. Moreover, precisely because at the outset of the argumentative exchange the balance of available reasons warrants the inference of the status quo, it would be irrational because it would disregard such formally correct inference - to ask those who defend the status quo to put forward any reason in support of it. Instead, the burden of proof has to lie with those seeking to change the status quo. It is for them to put forward sufficient reasons to disrupt the initial inference. One might wonder whether the burden of proof might 'shift' to those defending the status quo, once the party seeking the change has provided some reasons, albeit insufficient for the change. The answer to this question is, clearly, negative. Given that in the envisaged situation the status quo is still warranted by the balance of available reasons, those defending the status quo need not provide any additional reason for it to be maintained.

Considering the argumentative context of the criminal trial, then, the claim advanced here is that the rule allocating to the prosecution the burden of proving criminal responsibility is not justified by the value of protecting the innocent from conviction, or - following Lippke - by the value of protecting the rights that the defendant enjoys in the status quo and may cease to enjoy if convicted; rather, it is justified by the consideration that - whatever the rights enjoyed in the status quo and infringed by a conviction - it would be irrational to allocate the burden of proof otherwise, since it would contradict the principle of inertia. This claim, though, needs careful explanation.

Since respect for the principle of inertia is a requirement of rationality, in the justification of the component of the presumption discussed here the principle takes priority over the reasons normally advanced in the literature and just rehearsed. How so? First, consider that following these reasons in the allocation of the burden of proof may well be a requirement of reasonableness, but is not demanded by rationality itself. Reasonableness consists in more than mere formal correctness of reasoning. It $^{36}$ also

\footnotetext{
${ }^{35}$ More precisely, the conclusion is linked to the premises by a motivational means-end connection. On the role of means-end connections in practical inference see R. Audi, Practical Reasoning (London: Routledge, 1989) 95-102; G. E. M. Anscombe, 'Practical Inference' in M. Geach and L. Gormally (eds), Human Life, Action and Ethics: Essays by G. E. M. Anscombe (Exeter: Imprint Academic, 2005).

${ }^{36}$ The reference here is to practical, rather than theoretical, reasonableness. Besides validity, the latter only requires that the beliefs involved in the instance of reasoning be epistemically sound. On this distinction see Picinali, 'Two Meanings', supra note 4, at 857-862.
} 
involves respect for the moral values that are relevant to the particular instance of decision making. ${ }^{37}$ Hence, the decision of the legislator in the example described earlier may be unreasonable, insofar as making an extensive use of reverse burdens disrespects the value of protecting the innocent from conviction, and if this is indeed a value that should be acted upon, in particular, in deciding on the allocation of the burden of proof. However, as previously shown, that decision is rational because it originates from an inference that is formally correct. Protecting the innocent from conviction - or the defendant's rights, for that matter - are not requirements for the formal correctness of reasoning. ${ }^{38}$

Second, as the above characterisations of rationality and of reasonableness make clear, whilst rationality does not presuppose reasonableness, rationality is a necessary condition for reasonableness. ${ }^{39}$ The conceptual point advanced here conforms with the common sense intuition that a decision, an action, a plan, etc. cannot be reasonable if they are irrational. Consider someone who has a goal $\mathrm{A}$, believes that $\mathrm{B}$ is not a means to achieve $A$, and nonetheless decides to perform $B$ in order to achieve $A$. This instance of decision making would be unreasonable even if $\mathrm{A}$ and $\mathrm{B}$ were morally appropriate, and even if the belief that $B$ is not a means to achieve $A$ were accurate. The unreasonableness of this line of reasoning derives from its being an invalid inference, that is, from its irrationality. Similarly, changing the status quo in the presence of insufficient reasons for the change would be unreasonable even if such reasons were morally appropriate. The unreasonableness of this behavior derives from the fact that,

\footnotetext{
${ }^{37}$ In fact, practical reasonableness also requires that the beliefs involved in the instance of reasoning be epistemically sound. See Picinali, 'Two Meanings', supra note 4, at 860-862. The connection between practical reasonableness and morality is generally accepted and discussed in the literature. See Sibley, supra note 34; Perelman, supra note 34, at 124-133; J. Finnis, Natural Law and Natural Rights (Oxford: Clarendon Press, 1980), at 100-133; Rawls, supra note 34, at 48-54; von Wright, supra note 33, at 173; M. Moore, 'On Reasonableness' (1996) 13 Journal of Applied Philosophy 167, at 175-177; J. Rawls, Justice as Fairness: A Restatement (Cambridge (MA): Belknap Press, Erin Kelly ed., 2001), at 7; M. Moran, Rethinking the Reasonable Person: An Egalitarian Reconstruction of the Objective Standard (Oxford: Oxford University Press, 2003), at 286-316; A. Wierzbicka, English: Meaning and Culture (Oxford: Oxford University Press, 2006), at 131, 136; N. MacCormick, Practical Reason in Law and Morality (Oxford: Oxford University Press, 2008), at 156-161; T. A. Spragens, Jr., 'Democratic Reasonableness' in S. P. Young (ed), Reasonableness in Liberal Political Philosophy (London: Routledge, 2009), at 91-93; Alexy, supra note 34, at 5, 6; G. Sartor, 'A Sufficientist Approach to Reasonableness in Legal Decision-Making and Judicial Review' in Bongiovanni et al., supra note 34, at 17-19.

${ }^{38}$ It may be that in specific instances of reasoning the premises warrant a decision to protect the innocent, such that it would be irrational to decide otherwise. This, however, does not make the protection of the innocent a requirement of rationality. Rationality, instead, requires respecting the formal correctness of reasoning which, in such specific instances, would demand a decision to protect the innocent.

${ }^{39}$ Rationality, though, is not a sufficient condition for reasonableness. As pointed out earlier in the text, and in footnote 37, reasonableness also requires that the premises of an instance of reasoning be morally and epistemically sound. On the distinction between reasonableness and rationality see Picinali, 'Two Meanings', supra note 4, at 855-862. See also Alexy, supra note 34; Sartor, supra note 37; Sibley, supra note 34; Perelman, supra note 34, Ch. 11; Rawls, supra note 34, at 48-54; and A. Aarnio, The Rational as Reasonable: A Treatise on Legal Justification (Dordrecht: D. Reidel Publishing Company, 1987).
} 
in such instance, rationality demands that the status quo be maintained, since it is still warranted by a correct inference.

The upshot of this discussion is that requirements of rationality - such as the respect for the principle of inertia - are also requirements of reasonableness. Instead, other requirements of reasonableness - as the protection of the innocent from conviction, and of defendants' rights generally, may be - are just requirements of reasonableness, period. Requirements of the former kind are, therefore, more basic and richer than requirements of the latter. On this ground, they can be taken to enjoy priority. In the justification of the component of the presumption of innocence discussed here, then, the principle of inertia can be taken to enjoy priority over the reasons normally advanced in the literature. In fact, in addition to being of secondary importance, these reasons are not even necessary to achieve such justification. As shown earlier, the principle of inertia can achieve it by itself. To clarify, the point here is not that the value of protecting the innocent and, more generally, the defendant's rights are not reasons for allocating the burden of proof to the prosecution. Rather, it is that they are not necessary reasons, and that they take the backseat with respect to the principle of inertia. Of course, this holds only if we value rationality and reasonableness as principles informing the criminal process. If we didn't so value them, the relationship of priority defended earlier would be irrelevant in this context and the principle of inertia would have little or no normative power therein. The author doubts, though, that anyone would argue that we shouldn't thus value these qualities of reasoning.

At this point, one might object that it has not been shown that the principle of inertia is necessary to justify the rule on the allocation of the burden of proof. This is correct, but there is no need to do so. By showing that the principle of inertia is sufficient for this justification, it was also shown that the traditional justification is not necessary. And by showing that the principle of inertia takes priority over the traditional justification, it was also shown that, as things stand, it gives us the strongest justification for the rule.

\subsubsection{Inertia and the legitimacy of reverse burdens}

In recent years, there has been a lively debate on whether the rule allocating to the prosecution the burden of proving the defendant's criminal responsibility is compatible with reverse burdens, that is, burdens of proof allocated to the defence; ${ }^{40}$ and a related debate between substantivist and proceduralist conceptions of the presumption of innocence. The author has dealt with these issues elsewhere. ${ }^{41}$ For the sake of completeness, a restatement of these debates, as well as of the author's position in them, is offered here. This is done with an eye to adding more detail to the rule on the allocation of the burden of proof discussed and defended in the previous two

\footnotetext{
${ }^{40}$ The reference here is to the 'legal', as opposed to the 'evidential', burden. Reversing the latter is generally considered unproblematic. This distinction will be introduced later in the section, along with an explanation of the implications that the principle of inertia has for reversing either type of burden. ${ }^{41}$ See Federico Picinali, 'Innocence and Burdens of Proof in English Criminal Law' (2014) 13 Law, Probability, and Risk 243.
} 
subsections, and to clarifying the implications that the principle of inertia has for the legitimacy of reverse burdens. Those who seek a more comprehensive treatment, though, can consult the author's previous work.

In a nutshell, substantivists argue that the presumption of innocence is - among other things $-{ }^{42}$ a substantive law norm governing choices of criminalisation. ${ }^{43}$ According to this view, for a choice of criminalisation to be legitimate, it has to comply with the presumption of innocence; and compliance with the presumption requires that the criminal law norm at issue identifies conduct that is, indeed, worth criminalising and punishing. ${ }^{44}$ This means that the presumption of innocence may be breached even if there is no reverse burden of proof at play. Substantivists have argued, for instance, that strict-liability offences may be incompatible with the presumption of innocence in virtue of not including a mens rea element and, therefore, of not identifying conduct that is worth criminalising and punishing. ${ }^{45}$ If there is a reverse burden, instead, the presumption is complied with as long as the offence, construed as comprising all facts that are relevant to the defendant's responsibility aside from the fact that is the object of the reverse burden, consists in conduct that is worth criminalising and punishing. Indeed, in the presence of a reverse burden the law authorises a conviction even if the prosecution offers no proof of the fact that is the object of the reverse burden. Hence, when assessing whether the offence is worth criminalising and punishing - as the presumption allegedly requires - the offence must be considered as not including such a fact. ${ }^{46}$

Proceduralists, instead, deny that the presumption of innocence is a substantive law norm. ${ }^{47}$ The argument in defence of proceduralism that was advanced in the author's

${ }^{42}$ Being a substantivist does not preclude believing that the presumption of innocence performs also roles other than that defining substantivism. Substantivists may claim, for instance, that the presumption includes a rule on how the suspect/accused should be treated or a rule defining the point of departure of the fact finder's task.

${ }^{43}$ See R. J. Allen, 'Mullaney v. Wilbur, the Supreme Court, and the Substantive Criminal Law - An Examination of the Limits of Legitimate Intervention' (1977) 55 Texas Law Review 269; J. C. Jeffries \& P. B. Stephan, 'Defenses, Presumptions, and Burden of Proof in the Criminal Law' (1979) 88 Yale Law Journal 1325; R. J. Allen, 'Structuring Jury Decisionmaking in Criminal Cases: A Unified Constitutional Approach to Evidentiary Devices' (1980) 94 Harvard Law Review 321; L. B. Schwartz, "“Innocence" A Dialogue with Professor Sundby' (1989) 41 Hastings Law Journal 154; R. A. Duff, 'Strict Liability, Legal Presumptions, and the Presumption of Innocence', in A. P. Simester (ed.), Appraising Strict Liability (Oxford: OUP, 2005), at 133-137; V. Tadros and S. Tierney, 'The Presumption of Innocence and the Human Rights Act' (2004) 67 Modern Law Review 402

${ }^{44}$ Of course, the notion of 'conduct that is worth criminalising and punishing' needs to be spelled out by any substantivist conception of the presumption of innocence. But this is not an issue with which this article is concerned.

${ }^{45} \mathrm{Cf}$. Tadros and Tierney, supra note 43, at 422-424. Consider also Duff, supra note 43.

${ }^{46}$ See Picinali, supra note 41, at 245.

${ }^{47}$ See S. E. Sundby, 'The Reasonable Doubt Rule and the Meaning of Innocence' (1989) 40 Hastings Law Journal 457; S. E. Sundby, 'The Virtues of a Procedural View of Innocence - A response to Professor Schwartz' (1989) 41 Hastings Law Journal 161; P. Roberts, 'The Presumption of Innocence Brought Home? Kebilene Deconstructed' (2002) 118 LQR 41; P. Roberts, 'Drug Dealing and the Presumption of Innocence: The Human Rights Act (Almost) Bites' (2002) 6 E\&P 17; P. Roberts, 'Strict Liability and the 
previous work on the issue ${ }^{48}$ starts by pointing out that - as article 6(2) ECHR makes clear - the presumption of innocence becomes operative only when someone has been 'charged with a criminal offence'. If the presumption were a substantive law norm governing the choice of criminalisation, though, there would be no convincing reason to restrict its application to a stage where this choice has already been made and acted upon. It follows that the presumption of innocence is not a norm of this kind; instead, it is a procedural norm, that is, a norm that contributes to regulating the process through which an individual is investigated and, possibly, tried in order to assess whether they have committed a crime. ${ }^{49}$ An implication of this argument is that an offence cannot be in breach of the presumption of innocence if it does not feature a reverse burden of proof. The presumption of innocence being a procedural norm, it can be relied upon to scrutinise procedural practices or other procedural norms, such as reverse burdens; not to scrutinise norms of substantive law, such as those defining offences. Another implication of the argument is that whether a reverse burden breaches the presumption of innocence does not depend on the substantivists' test whether the offence would be worth criminalising and punishing without the fact that is the object of the reverse burden. This test raises a substantive issue on which the presumption of innocence has nothing to say.

Two important questions remain, though: under proceduralism, does the presumption of innocence admit of reverse burdens? If so, when are these legitimate? Being a proceduralist, in fact, does not commit someone to answering these questions in any particular way. Proceduralism is the rejection of substantivism, not a fullyfledged theory on the legitimacy of reverse burdens. To answer these questions, then, it is necessary to rely on the normative foundations of the aforementioned rule on the allocation of the burden of proof, that is, on the principle of inertia.

As seen earlier, the principle of inertia is silent with respect to which reasons are sufficient for a change of the status quo. It includes no prescription concerning the facts that constitute criminal responsibility or the standard of proof that needs satisfying in order to consider these facts established. This means that, as far as the principle is concerned, the legislator is free in their choice of which facts are necessary for criminal responsibility - a state of affairs that tallies with the proceduralist approach endorsed here. Of course, both the legislator in defining crimes, and the court in interpreting statutes, are generally expected to comply with a series of guiding norms. ${ }^{50}$ These norms, though, are independent of the principle of inertia.

Presumption of Innocence: An Exposé of Functionalist Assumptions' in Simester (ed.), supra note 43; Roberts \& Zuckerman, supra note 7, at 282-290.

${ }^{48}$ See Picinali, supra note 41, at 251-255.

${ }^{49}$ The fact that the ECtHR adopts an interpretation of 'criminal charge' that is autonomous from, and more extensive than, domestic classifications (see Trechsel, supra note 5, at 31-33) does not undermine the point advanced here that the act of criminalisation - hence the definition of a crime - is a necessary condition for the operation of the presumption of innocence.

${ }^{50}$ For instance, the principle according to which the criminal law should be used only to prevent harm to others (i.e., the Millian 'harm principle'), the principle according to which the criminal law should 
The facts that are necessary for someone to be responsible for a given crime are referred to here as the 'constitutive facts' for that crime - to reflect their role in constituting criminal responsibility. ${ }^{51}$ Since conviction for a crime presupposes that the defendant is responsible for it, conviction presupposes the occurrence of all constitutive facts for that crime. Needless to say, the full list of constitutive facts for a given crime may not always be evident from the statute and may emerge only as a result of careful interpretation. Still, it must be identified for the criminal law to be operationalised in court - in particular, for it to be possible to decide whether the defendant is responsible for the crime at issue. Notice that the concept of constitutive facts adopted here does not track the traditional formalistic divide between elements of the offence and defences. In other words, the concept of constitutive facts is not coextensive with the concept of elements of the offence. Indeed, the legislator or the interpreter may well consider that the absence of what is traditionally called a defence - e.g., duress or insanity - is necessary in order to be responsible for a certain crime. If so, it would be a constitutive fact for that crime, even if the absence of such a defence is not traditionally referred to as element of an offence. Now, according to the principle of inertia, in the absence of sufficient reasons to the contrary, the status quo must be preserved. In the argumentative context of the criminal trial, the change in the status quo is represented by the conviction of the defendant, with the accompanying punishment. Since conviction for a given crime presupposes that the defendant is responsible for it, in said argumentative context the sufficient reasons mentioned by the principle of inertia must include the proof of all constitutive facts for such crime. As seen earlier, the principle implies that it is for the party seeking the change to provide sufficient reasons for it. Hence, the prosecution must prove all constitutive facts in order to obtain a conviction. ${ }^{52}$ Given that a conviction at trial does not

be resorted to as an ultima ratio, and the principle of fair labelling (on these and other basic principles of criminal law see J. Horder, Ashworth's Principles of Criminal Law (OUP $8^{\text {th }}$ edn. 2016) Ch. 4)). An important principle of statutory interpretation is the presumption that mens rea is an essential ingredient of every offence (see Sweet v Parsley [1969] 53 Cr App R 221, in particular, at 224), which is accompanied by a test setting out the conditions under which the presumption may be rebutted (see Gammon Ltd. v Attorney General of Honk Hong [1985] 80 Cr App R 194, in particular, at 199). Moreover, sections 3(1) and 4(2) of the Human Rights Act 1998 confer on the courts the power to implement Convention rights either through interpretation or through a declaration of incompatibility. This means that courts are allowed to alter or censure a criminal provision that constitutes an unjustified interference with, in particular, the right to privacy, freedom of thought, conscience and religion, freedom of expression, and freedom of assembly and association.

${ }^{51}$ In fact, some statutes may allow for a crime to be committed in alternative ways, such that there are facts which are rightfully considered constitutive of criminal responsibility, but cannot be described as necessary for it. Examples of this phenomenon are not rare, but a particularly clear one is offered by section 9 Theft Act 1968, proscribing burglary. In these cases, among the necessary conditions for criminal responsibility is the truth of a disjunction of two or more facts.

52 The problem may seem more complex in the case of an aggravated offence. Why - someone may ask - shouldn't the principle of inertia allow for a reverse burden on the aggravating fact, notwithstanding that this is perforce a constitutive fact -i.e. a fact that is necessary for someone to be deemed responsible for the aggravated offence? After all, if the prosecution proves the other constitutive facts of the 
presuppose anything more than criminal responsibility - aside from the obvious fact that the defendant is alive! - the prosecution need not prove any additional fact.

It is worth clarifying that the principle of inertia requires that the prosecution bear both the 'evidential' and the 'legal' burdens with respect to constitutive facts. The former is the burden to introduce enough evidence to raise an issue for the court to consider; in other words, it is the burden to convince the court that it should instruct the fact finder to make a determination on the fact at issue. The latter, instead, is the burden to convince the fact finder that such fact occurred. ${ }^{53}$ Allocating to the defence the evidential burden on any constitutive fact would amount to assuming that such a fact occurred, absent some evidence to the contrary to be offered by the defence. This would mean that the prosecution could obtain a conviction - hence a change in the relevant status quo - without providing any evidence whatsoever of that fact. This runs against the rule - defended earlier on the basis of the principle of inertia - that the prosecution must prove all constitutive facts in order to obtain a conviction. Moreover, this rule would also be flouted if, whilst bearing the evidential burden on all constitutive facts, the prosecution did not bear the legal burden on one or more of them. Indeed, proving a fact in the context of the criminal trial means producing enough evidence to convince the fact finder that such fact occurred. The legal burden is precisely the burden to produce such evidence. Hence, the legal burden should be on the prosecution for all constitutive facts. Failing this, the prosecution might obtain a conviction - thus, a change in the status quo - without giving sufficient evidence - that is, reasons - for it.

The principle of inertia, then, demands that the prosecution bear both the evidential and the legal burdens on all facts that are necessary for the defendant to be responsible for the crime charged. The question remains whether the evidential or legal burdens on any fact other than the constitutive facts can ever be allocated to the defence.

The principle of inertia implies that, with respect to additional facts that overlap with the constitutive facts, neither the evidential burden, nor the legal burden, can be allocated to the defence. In case of non-overlapping facts, instead, both the evidential and the legal burden can thus be allocated, without contradicting the principle. A fact is said here to overlap with the constitutive facts if it negatives one or more of such facts. ${ }^{54}$ Imagine, for example, that the constitutive facts for the crime of murder were exclusively the identity between the perpetrator and the defendant and, indeed, the facts included in the description of this crime given by English and Welsh law: the

aggravated offence, it does establish the basic offence, thus providing sufficient reasons for a change of the status quo. This view is clearly mistaken, since it assumes that giving sufficient reasons for $a$ particular change of the status quo justifies any change of it. With a reverse burden on the aggravating fact, the prosecution would be allowed to obtain a change of the status quo having given sufficient reasons only for a less profound change than this, that is, for the change that is justified by establishing the basic offence only. This undermines the principle of inertia. See also supra footnotes 23 and 30.

${ }^{53}$ On this distinction see, among others, Dennis, supra note 14, at 441-445.

${ }^{54}$ Cf. Paul Robinson' notion of 'failure of proof defences'. See P. H. Robinson, 'Criminal Law Defenses: A Systematic Analysis' (1982) 82 Columbia Law Review 199, at 204-208. 
unlawful killing of another human being in the Queen's peace, performed with the intention to cause the death of, or grievous bodily harm to, this being. ${ }^{55}$ If so, selfdefence would overlap with these constitutive facts, because it negates unlawfulness. Instead, loss of control - at least as it is currently defined in sections 54 and 55 of the Coroners and Justice Act 2009 - would not overlap with these constitutive facts, as it negates none of them. Another example of a fact that would not overlap is the fact of having committed the crime out of mercy. Because non-overlapping facts do not negate any constitutive fact and, therefore, do not deny the responsibility for the crime at issue, should they be recognised by the substantive law their most likely role would be that of mitigating the sentence that would be justified by the constitutive facts for that crime. Consider that under English and Welsh law loss of control does not merely mitigate the sentence for murder; it denies the responsibility for murder, rendering the perpetrator responsible for the lesser offence of voluntary manslaughter. Given this, it appears that - unlike in our example - under said law the absence of loss of control is indeed a constitutive fact for the crime of murder; ergo, loss of control is an overlapping fact.

In any case, allocating to the defence the evidential and/or legal burden on an overlapping fact would contradict the rule that the prosecution should bear both the evidential and the legal burdens on all constitutive facts; it would, thus, contradict the principle of inertia. Indeed, a reverse legal burden on an overlapping fact is equivalent to allocating to the defence the legal burden to negative one or more constitutive facts. And a reverse evidential burden on an overlapping fact is equivalent to allocating to the defence the evidential burden on one or more constitutive facts: more precisely, the burden to convince the court that such constitutive fact(s) should not be assumed, but should instead be the object of a determination by the fact finder. Returning to our hypothetical, then, neither the legal nor the evidential burdens on self-defence should be borne by the defence. The prosecution should bear the full burden to show that the defendant acted unlawfully; hence, not in self-defence. Instead, both the legal and the evidential burdens on loss of control - and on the motive of mercy - can be allocated to the defence, with no detriment to the principle of inertia. ${ }^{56}$ To reiterate a point made

\footnotetext{
${ }^{55}$ J. Herring, Criminal Law: Text, Cases, and Materials (OUP $8^{\text {th }}$ edn., 2018), at 223. Cf supra note 51 with reference to the disjunctive mens rea in the case of 'murder'.

${ }^{56}$ Under English and Welsh law, the defendant bears the evidential burden both in the case of selfdefence and in the case of loss of control. The legal burden, instead, lies with the prosecution in both cases. On self-defence see Woolmington, supra note 1, R. v Lambert [2001] UKHL 37, para. 82, and R. v Bone [1968] 1 WLR 983, at 985. On loss of control see s54(5) Coroners and Justice Act 2009. If unlawfulness is indeed a constitutive fact for the crime of murder under English and Welsh law, then this law is at odds with the principle of inertia, since it allocates to the defence the evidential burden on self-defence. To be sure, many would argue that the absence of self-defence should straightforwardly be considered a constitutive fact. If this argument is correct, English and Welsh law is a fortiori at odds with the principle of inertia. As pointed out in the text - and contrary to the example given - loss of control appears to be an overlapping fact under English and Welsh law. If so, the allocation of the evidential burden on loss of control to the defence contradicts the principle of inertia. The motive of
} 
earlier, the identification of the constitutive facts for a given crime is a matter of substantive law on which the principle of inertia - hence, the presumption of innocence - have nothing to say. Once the legislator and the interpreter have identified these facts, though, the principle allows for reverse evidential and/or legal burdens only on non-overlapping facts - assuming that there is any such fact that is recognised by the substantive law.

In conclusion, according to the principle of inertia the issue of the legitimacy of reverse burdens should be addressed by applying the criteria of constitutive facts and of overlapping facts. Neither the evidential nor the legal burden of proof on any of these facts can be allocated to the prosecution without contradicting the principle. Needless to say, this approach differs markedly from that adopted by the ECtHR and by English courts. The ECtHR has suggested that reverse burdens are legitimate if used within 'reasonable limits', ${ }^{57}$ but has then failed to articulate a clear test for applying this threshold. ${ }^{58}$ English courts too have fallen short of elaborating a coherent test for the legitimacy of reverse burdens. Instead, they have relied on a case-by-case approach, stressing in each case the importance of one or more relevant considerations. ${ }^{59}$ Moreover, they have often strayed towards an unwarranted substantivist position. ${ }^{60}$

\subsection{The standard of proof}

So far, the article has defended the view that the presumption of innocence includes a rule on the allocation of the burden of proof. It is now time to consider other possible components of the presumption.

According to art. 6(2) ECHR, the presumption of innocence operates until the defendant is 'proved guilty' of a crime. Some scholars straightforwardly treat the presumption as including the requirement that guilt should be considered proven only when the standard of proof beyond a reasonable doubt has been satisfied. ${ }^{61}$ As pointed out earlier, this reading is in accord with the common law conception of the presumption. ${ }^{62}$ The more cautious scholars, instead, point out that the presumption of

\footnotetext{
mercy is not recognised as a defence to murder in England and Wales. See R(Nicklinson) v Ministry of Justice [2014] UKSC 38.

${ }^{57}$ Salabiaku v France (Application no. 10589/83) (1991) 13 EHRR 379, at 388.

${ }^{58}$ See Trechsel, supra note 5, at 168-171 and Jackson and Summers, supra note 7, at 221-228. As with other areas of its case-law, the ECtHR seems to favour here a proportionality test. This test consists in the assessment whether the infringement of an ECHR right (represented, in this case, by the reverse burden) is proportionate to the aim that the legislator is seeking to achieve. This aim - which is invariably that of increasing the enforcement of certain crimes - has to be assessed for its legitimacy. The ECtHR's proportionality test, though, has never been clearly fleshed out.

${ }^{59}$ See Jackson and Summers, supra note 7, at 227-228 and Dennis, supra note 14, at 458-479. Among the factors considered by English courts are the maximum penalty, the relative ease of proof of the fact at issue, and whether this fact is part of the 'gravamen' of the offence.

${ }^{60}$ See Picinali, supra note 41, at 248-251 and Jackson and Summers, supra note 7, at 228.

${ }^{61}$ See Schwikkard, supra note 14, at 29 and Jackson and Summers, supra note 7, at 200-204, 211-215.

${ }^{62}$ See supra notes 6 and 7 and accompanying text.
} 
innocence, as stated in art. 6(2) ECHR, is silent about the requisite standard of proof for a 'guilty' verdict. Still, they argue that the very reasons that justify the rule on the allocation of the burden of proof also justify adopting the standard of proof beyond a reasonable doubt. In particular, this high standard is required by the need to protect the innocent from conviction. On these grounds, they are satisfied that the presumption can be read as encompassing the reasonable doubt standard. ${ }^{63}$

The view favoured here is that according to which the presumption of innocence does not require a specific standard for the proof of criminal responsibility. ${ }^{64}$ This is not so much because of the trivial exegetic point that there is no word in art. 6(2) ECHR that clearly indicates a particular decision rule - neither the term 'proved', nor the phrase 'according to law' do so. ${ }^{65}$ It is because the considerations that are generally deemed relevant for the selection of the standard of proof do not play any role in the justification of the rule on the burden of proof. ${ }^{66}$ As shown earlier, in order to justify this rule there is no need to appeal to the value of protecting the innocent from conviction or, more generally, of protecting the defendant's rights. The rule on the burden of proof is justified by the principle of inertia, which is itself silent with respect to the standard of proof to be adopted. If the standard of proof and that which is generally considered the core component of the presumption of innocence are indeed justified by distinct arguments and reasons, the possibility of reading the former into the presumption seems to vanish.

What if the justification of the rule on the burden of proof advanced here were mistaken? What if, in fact, the value of protecting the innocent from conviction were crucial to justifying such a rule? Would this mean that the standard of proof - the reasonable doubt standard, in particular - could safely be read into the presumption of innocence? The answer to this last question is negative. The argument, advanced in the literature, that relies on an alleged affinity between the justification of the rule on

\footnotetext{
${ }^{63}$ See Ashworth, supra note 14, at 250-251; Campbell, supra note 14, at 683; Duff, supra note 43, at 133134. But see Trechsel, supra note 5, at 154, suggesting - somewhat surprisingly - that the standard of proof beyond a reasonable doubt is 'implied by the words "presumed innocent until proved guilty"' used in art. 6(2) ECHR. Consider also Thayer, supra note 13, at 194. Referring to Fitzjames Stephen's view that the presumption of innocence includes the standard of proof beyond reasonable doubt, Thayer writes: 'it seems plain that such a statement adds something to the mere presumption of innocence, for that, pure and simple, says nothing as to the quantity of evidence or strength of persuasion needed to convict.' Similarly, Wigmore states that the presumption 'says nothing' about 'the measure of persuasion'. See John H. Wigmore, A Treatise on the Anglo-American System of Evidence in Trials at Common Law. Vol 9 (Little Brown, 1940, $3^{\text {rd }}$ edition), at 407.

${ }^{64}$ In a private exchange, Antony Duff advanced the theory that there isn't $a$ presumption of innocence; rather, there are several presumptions that apply to different authorities in different phases of the criminal process. What differentiates these presumptions from each other is the standard of proof that each presumption allegedly prescribes. If the conception of the presumption of innocence defended in this article were correct, a theory such as Duff's could not get off the ground. This is because, according to this conception, the presumption of innocence does not include a standard of proof.

${ }^{65}$ Cf. Trechsel, supra note 5, at 161-162. For Trechsel's view see also supra note 63.

${ }^{66}$ For a comprehensive account of the debate about the justification of the reasonable doubt standard, see Picinali, 'Can the Reasonable Doubt Standard Be Justified?', supra note 4.
} 
the burden of proof and the justification of the reasonable doubt standard in order to read the latter into the presumption of innocence, is built on a dangerously simplistic understanding of the justification of the criminal standard of proof. As made evident by recent developments in the debate on the justification of the reasonable doubt standard, ${ }^{67}$ one cannot safely claim to be able to justify any criminal standard of proof by relying exclusively on the consideration that it is necessary to protect the innocent from conviction, or the defendant's rights for that matter. Given the apparently competing goals of a criminal justice system (including the conviction of the guilty, the protection of the polity from crime, the fairness of the trial, and the protection of the innocent from conviction), and the fact that the stringency of the standard of proof may have implications for the achievement of these goals, ${ }^{68}$ any justification of the standard must be substantially more complex than this. ${ }^{69}$ If so, protecting the innocent from conviction would be hardly sufficient as a common denominator to claim a significant similarity between the justification of the rule on the burden of proof and the justification of the standard of proof. Hence, the argument that the standard of proof - the reasonable doubt standard, in particular - should be read into the presumption of innocence cannot be built on this premise alone. The need to protect the innocent or the defendant may certainly contribute to the choice of a standard of proof; but to the extent that other goals are involved in such a choice and that these goals are not reflected in the mainstream justification of the rule on the burden of proof, it is difficult to see how those offering this justification can read the standard into the presumption. ${ }^{70}$

\subsection{A rule defining the point of departure of the fact finder's task}

\footnotetext{
${ }^{67}$ These developments are reported and critically assessed $i b i d$.

${ }^{68}$ See ibid for an assessment of the relationship between the relevant goals within the discussion of the justification of the standard of proof.

${ }^{69}$ One could have a similar understanding of the problem of allocating the burden of proof, and argue that whether in some cases the burden should be reversed should depend on a careful assessment of the expected costs and benefits of so doing, as calculated in light of the goals of the system. Under this theory, the allocation of the burden of proof is not determined exclusively by the need to protect the innocent from conviction - as it is according to the mainstream view - but depends also on the other (apparently competing) values that the system cherishes. Cf. David Hamer, 'A Dynamic Reconstruction of the Presumption of Innocence' (2011) 31 Oxford Journal of Legal Studies 417, and David Hamer, 'Presumptions, Standards, and Burdens: Managing the Cost of Error' (2014) 13 Law, Probability, and Risk 221.

${ }^{70}$ Richard Lippke's theory of the presumption is a case apart. As seen earlier, he ultimately justifies the presumption of innocence on the basis of the value of protecting the defendant's rights. Whilst he reads the standard of proof into the presumption, he also offers an argument to the effect that the competing value of convicting the guilty should not play a role in the choice of the standard. See Lippke, supra note 14, at 121-126. A similar argument was presented in Picinali, 'Can the Reasonable Doubt Standard Be Justified?', supra note 4 . The author must confess that he now finds the argument unpersuasive. This discussion, however, falls outside the scope of this article.
} 
Some prominent scholars have argued that the presumption of innocence includes a rule imposing on the fact finder a particular cognitive attitude to be adopted at the start of the trial.

Recently, Richard Lippke defended the view that the presumption should be interpreted so as to require that 'jurors ... begin the trial by viewing the accused as if they are citizens in good standing in their communities.... Accused persons need not be viewed as morally perfect or even exemplary citizens, only as materially innocent of the charges against them' ${ }^{71}$ The plainest reading of the requirement theorised by Lippke is that it demands that at the start of the trial the fact finder believe that the defendant is in fact innocent of the crime charged. This reading lends itself to the obvious objection that a requirement that someone believe something is fundamentally defective, since beliefs are not the sort of attitude that can be adopted at will. ${ }^{72}$ Being aware of this objection, Lippke attempts to dodge it by clarifying how his requirement should be interpreted. ${ }^{73}$ He states explicitly that the requirement does not impose a belief. He then offers a series of characterisations of the cognitive attitude imposed by the requirement, calling it a 'rebuttable presumption on the accused' and a 'viewpoint on the accused'. ${ }^{74}$ These characterisations, however, fall far short of pinning down the nature of this attitude. His treatment of the objection concludes with an ambiguous passage: '[the presumption] should be interpreted not as telling jurors to somehow magically come to believe in the material innocence of the accused, but as telling them to view the government's case through the lens of the accused's presumed material innocence. ${ }^{\prime 75}$ Notwithstanding Lippke's protestation that his requirement does not impose a belief, it remains unclear what other cognitive attitude the requirement may be imposing. This makes it impossible to assess whether this attitude can indeed be adopted at will; thus, whether the requirement that Lippke theorises does avoid the objection just raised.

One may try to salvage Lippke's theory by taking a clear stance as to which cognitive attitude the fact finder is required to adopt, choosing an attitude that can be adopted at will. A possible candidate is a propositional imagining. According to this restatement of Lippke's theory, the fact finder should start the trial imagining that the defendant is a citizen in good standing in the community, that she is in fact innocent of the crime charged. This imagining would constitute the framework upon which the fact finder should lay all the evidence presented at trial, so as to assess the case against the defendant. Similarly to beliefs, propositional imaginings are representations to oneself that something is the case. Differently from beliefs, though, propositional imaginings do not 'aim' at the truth of the proposition constituting their object. In other

\footnotetext{
${ }^{71}$ See Lippke, supra note 14 , at 84.

${ }^{72}$ On this point see Picinali, 'Two Meanings', supra note 4, at 852 and the philosophical literature referenced there. See also Roberts, supra note 12, at 16, for an argument akin to that presented here against Lippke's theory.

${ }^{73}$ See Lippke, supra note 14, at 13, 100-101.

${ }^{74} \mathrm{Id}$. at $100-101$.

${ }^{75}$ Ibidem.
} 
words, whilst an individual cannot really believe in a state of affairs unless she regards the state of affairs to be true, ${ }^{76}$ she can certainly imagine such state of affairs without regarding it as true. ${ }^{77}$ Arguably, the fact that imaginings are not truth-directed is what makes it possible for us to imagine at will. ${ }^{78}$ Since our beliefs need to fit the world, we cannot believe in something just because we intend to do so. Our imagination, though, need not fit the world. We are, therefore, free to imagine whatever we intend to imagine.

Even if it is realistic to require that fact finders start the trial by imagining that the defendant has not committed the crime charged, it is unclear why we should so require. There is only one useful role of such a requirement: to prompt fact finders to ignore any incriminating evidence that they may have been exposed to before the trial, so that only the incriminating evidence presented at trial is relied upon. More will be said soon about the importance of pursuing the aim that fact finders adjudicate only on the basis of the evidence presented at trial. For now, it suffices to point out that in order to achieve this aim there is no need to require that fact finders imagine anything. A straightforward rule limiting the evidence that they can rely upon would be enough.

To conclude on Lippke's theory, a charitable interpretation of his words is that what he is defending is not at all a cognitive attitude towards the defendant, but a practical attitude towards the incriminating evidence. In other words, Lippke might be read as saying that the presumption of innocence requires fact finders to exercise particular caution when examining the evidence of the prosecution; greater caution than they should exercise when examining exculpatory evidence. Besides stretching the meaning of Lippke's words to a questionable extent, this interpretation does not provide a convincing argument. It is intrinsic in the task of the criminal fact finder that she should use great caution in examining all the available evidence, whether incriminating or not. Of course, the prosecution case, thus, the prosecution evidence should be subject to a more demanding test than the defence case; but this is required by the asymmetrical standard of proof that governs criminal fact finding, not by any supposed additional directive on the assessment of the evidence. And the standard of proof, as seen earlier, is not part of the presumption of innocence.

Differently from Lippke, Larry Laudan claims that the presumption of innocence requires that at the start of the trial the fact finder believe not in the defendant's actual

\footnotetext{
${ }^{76}$ On the truth-directedness of beliefs, see Bernard Williams, 'Deciding to Believe' in Problems of the Self (CUP, 1973) and David J. Velleman, The Possibility of Practical Reason (Oxford: Clarendon Press, 2000), at 250-252, stating at 251 that 'believing involves regarding a proposition as true with the aim of so regarding it only if it really is' true.

${ }_{77}$ On the difference between believing and imagining see Shen-Yi Liao and Tamar Gendler, 'Imagination' in Edward N. Zalta (ed.), Stanford Encyclopedia of Philosophy (Spring 2019 edition), at 8-11 and Gregory Currie and Anna Ichino, 'Imagination and Make-Believe' in Berys Gaut and Dominic McIver Lopes (eds.), The Routledge Companion to Aesthetics (Routledge 2013), at 321-323.

${ }^{78}$ Deliberate imagination is part of everyone's life. On the notion of 'deliberate imagining' see Kendall L. Walton, Mimesis as Make-Believe: On the Foundations of the Representational Arts (Harvard University Press, 1990), at 13-16. Walton points out that not all imaginings are deliberate. Some 'happen to us'. These he calls 'spontaneous' imaginings (ibidem).
} 
- or 'material' - innocence, but in her 'probatory' innocence. ${ }^{79}$ According to Laudan, this attitude involves not just the belief that the defendant has not been proven guilty according to the applicable standard of proof; but also the belief that there isn't yet any evidence against her. In other words, the fact finder should believe that the presence of the defendant in court and any other information that the fact finder may have been exposed to prior to the start of the trial provide no evidence of guilt. The requirement defended by Laudan is vulnerable to the objection, discussed earlier, that to require that someone believe something is to make a mistake about the nature of beliefs. ${ }^{80}$ Moreover, there is an issue with the propositional content of the belief theorised by Laudan. One should expect that at the outset of the trial every reasonable fact finder believe that the defendant has not been proven guilty according to the applicable standard of proof. A fact finder that believes otherwise is not someone that we should allow to adjudicate at all. So, even if it weren't mistaken, it would be superfluous to require that fact finders believe that the defendant has not been proven guilty. ${ }^{81}$ And, whilst safe from the earlier objection about beliefs, it would be equally superfluous to require fact finders to imagine this state of affairs.

Laudan's more stringent demand that at the start of the trial the fact finder believes that there isn't yet any evidence of guilt, derives from a rule that was recognised as part of the presumption of innocence by the US Supreme Court, and earlier by John Wigmore. This is the rule that the fact finder should decide the issue of guilt only on the basis of the evidence presented at trial, ${ }^{82}$ ignoring other incriminating evidence that she may be aware of - including the presence of the defendant in court and her arrest. ${ }^{83}$

\footnotetext{
${ }^{79}$ See Laudan, supra note 7, at 103-106. Laudan's terminology in referring to the cognitive attitude that he theorises is not always consistent, but in at least two passages - respectively at 103 and at 106 - he refers to it as a belief.

${ }^{80}$ When criticising the view of the presumption of innocence according to which the presumption imposes a belief in the material innocence of the defendant, Laudan gives the impression of being aware of this objection. See $i d$. , at 101. However, surprisingly he does not consider the consequences that this objection has for his own view.

${ }^{81}$ Cf. Ferguson, supra note 13, at 139.

${ }^{82}$ Of course, this rule should not be read as preventing the fact finder from filling in evidential gaps in the prosecution case by relying on common sense knowledge, i.e., knowledge about the world that we should expect any reasonable person living in our community to have.

${ }^{83}$ See Bell v Wolfish, supra note 7 - stating at 533 that the presumption 'may serve as an admonishment to the jury to judge an accused's guilt or innocence solely on the evidence adduced at trial and not on the basis of suspicions that may arise from the fact of his arrest, indictment, or custody, or from other matters not introduced as proof at trial' - and Wigmore, supra note 63, at 407 - stating that the presumption 'cautions the jury to put away from their minds all the suspicion that arises from the arrest, the indictment, and the arraignment, and to reach their conclusion solely from the legal evidence adduced'. The rule at issue is also discussed in Jackson and Summers, supra note 7, at 202, 203. Consider also Thayer, supra note 13, stating at 196: 'In saying that the accused person shall be proved guilty, it says also that he shall not be presumed guilty; that he shall be convicted only upon legal evidence, not tried upon prejudice; that he shall not be made the victim of the circumstances of suspicion which surround him, the effect of which it is always so difficult to shake off, circumstances which, if there were no emphatic rule of law upon the subject would be sure to operate heavily against him; the circumstances, e.g., that after an investigation by the grand jury he has been indicted, imprisoned, seated
} 
The rule ${ }^{84}$ fulfils a very important role, in that it allows the court to exercise control on the evidence that is relied upon at trial. This control is exercised through the rules of admissibility and it promotes important values - above all, the reliability of fact finding and the defendant's right to a fair trial. If fact finders were allowed to rely on incriminating evidence not presented at trial, these rules and values would be undermined. This said, it is doubtful whether the rule at issue should be considered part of the presumption of innocence.

The rule ostensibly applies to incriminating evidence only, but there is no reason why it should not be extended to exculpatory evidence. Even when exercised with reference to exculpatory evidence, the court's control over which evidence should be relied upon for fact finding promotes important values. For instance, by excluding irrelevant exculpatory evidence the court promotes the reliability of fact finding, or it may protect the dignity of a complainant by excluding information concerning her sexual history put forward by the defence. If the reason for having the rule is that it allows the court to exercise control over which items of evidence should be relied upon by the fact finder; and if this control is valuable even with regard to evidence of the exculpatory kind; then the rule should be extended so as to apply also to this kind of evidence. However, when the rule is so extended, it becomes harder to argue that it is a component of the presumption of innocence.

For those who argue that the presumption of innocence is primarily justified by the value of protecting the innocent from conviction, it would make little sense to read the presumption as including a rule that puts limits to the sort of exculpatory evidence that can be relied upon by the fact finder. The more the exculpatory evidence that the fact finder can use, the greater the protection for the innocent. One might object to this that if the presumption of innocence is about protecting the innocent, allowing the use of exculpatory evidence of a dubious epistemic status (as the out-of-court evidence may be) would sit uneasily with the presumption's function: it would unreasonably extend protection to the guilty. Hence, according to this objection the presumption may well include the rule at issue here. However, the more exculpatory evidence is admitted - even if of dubious epistemic status - the harder is the job of the prosecution to obtain a conviction and, consequently, the smaller is the risk that an innocent is convicted. If the protection of the innocent is what drives the presumption, then, a rule putting limits to the sort of exculpatory evidence that can be relied upon should not

in the prisoner's dock, carried away handcuffed, isolated, watched, made an object of distrust to all that behold him.' Thayer's remarks, though, are not made with reference to the presumption of innocence. The 'it' that he refers to at the start of the passage is the rule stating that the defendant should be proved guilty beyond a reasonable doubt - a rule that, as mentioned supra note 63 , Thayer considers separate from the presumption.

${ }^{84}$ Notice that this rule may be conceptualised as imposing a cognitive attitude on the fact finder, this being the propositional imagining that there is no incriminating evidence other than that presented at trial. This conceptualisation, though, is not necessary to understand or to enforce the rule. Therefore, it is left aside here. 
be part of it. This argument works a fortiori for the case in which the presumption is justified by the value of protecting the defendant's rights, rather than merely the innocent's.

Whilst the view defended here is that the presumption of innocence is not justified by the value of protecting the innocent from conviction, the author still considers that the rule that the fact finder should decide the issue of guilt only on the basis of the evidence presented at trial should be treated as separate from the presumption. Especially when understood in its extended version, this rule makes sense because of a fundamental normative feature of the criminal trial, i.e., that evidence should not be relied upon unless it meets certain criteria of admissibility. If there was no question of admissibility - that is, if any item of evidence could be relied upon by the fact finder what would be the reason for having such a rule? The rule seems indeed a corollary of the existence of a question of admissibility: out-of-court evidence has not passed the test of admissibility and, therefore, should be ignored. If, however, the rule already has a solid normative grounding in a fundamental feature of the trial, there is really no need to read it into the presumption of innocence. This conclusion receives additional support from the consideration that the rule does not seem to have any literal basis in art. 6(2) ECHR. Instead, with the expression 'until proved guilty according to law' art. 6(2) can be taken to defer completely to other norms for the determination of which evidence should and should not be relied upon by the fact finder.

\section{Possible components of the presumption relating to the treatment of the suspect/accused}

The interim conclusion after the previous section is that the presumption of innocence consists only in a rule allocating to the prosecution the burden of proving the defendant's criminal responsibility, and that this rule is justified by the principle of inertia in argumentation. But is there more to the presumption of innocence than this? Doesn't the presumption also include a rule of conduct on how to treat the suspect/accused?

Given the formulation of the presumption in art. 6(2) ECHR, one may be wary of interpreting it as including such a rule. If anything, to say that someone should be 'presumed innocent until proved guilty' is to demand a particular way of regarding, rather than treating, this individual. As the previous subsection showed, however, notwithstanding the formulation of art. 6(2) ECHR, it is doubtful whether the presumption imposes any particular way of regarding the defendant. If so, one should not rely on the formulation as a conclusive argument that the presumption does not impose a rule of conduct.

Indeed, it is widely accepted by academics and courts alike that the presumption includes the rule according to which throughout the criminal process the state 
authorities ${ }^{85}$ should treat the suspect/accused as innocent until she is found guilty of the crime charged.$^{86}$ Some authors even argue that this rule is a 'logical consequence' of the rule concerning the allocation of the burden of proof. According to these authors, if a guilty verdict is authorised only when the prosecution has proven its case to the satisfaction of the applicable standard, it follows that up to that point the suspect/accused should be treated as innocent of the crime charged. ${ }^{87}$ Later in the section this claim of logical relation will be reconsidered.

What does it mean, though, that the suspect/accused should be treated as innocent? It is useful to restate here the distinction relied upon earlier between actual - or material - innocence, and legal - or probatory - innocence. The former is the state of affairs consisting in not having committed the crime charged; the latter is the state of affairs consisting in not having been found guilty of the crime charged through the criminal process. Let's consider first a rule according to which the state authorities should treat the suspect/accused as actually innocent. Is this rule part of the presumption?

\subsection{Treating the suspect/accused as an 'actually' innocent person}

Of course, the rule stating that the state authorities should treat the suspect/accused as actually innocent is not premised on the assertion that the suspect/accused is actually innocent, this being a fact that we cannot know for certain even at the end of the trial. Rather, the rule hypothesises that she is actually innocent and invites the authorities to treat her according to this hypothesis. The rule should, therefore, be understood as requiring the state authorities to treat the suspect/accused as they should treat her if she were actually innocent.

Notice that this formulation of the rule is still elliptical. Consider that our agency is governed by our beliefs about the relevant matters, rather than by the actuality of the relevant matters - this being a state of affairs that we may not - possibly, cannot - have

\footnotetext{
${ }^{85}$ There are differing views as to whether this rule should also extend to agents other than the state authorities. Compare Antony Duff, 'Who Must Presume Whom to Be Innocent of What' (2013) 42 Netherlands Journal of Legal Philosophy 170 with Thomas Weigend, 'Assuming that the Defendant is Not Guilty: The Presumption of Innocence in the German System of Criminal Justice' (2014) 8 Criminal Law and Philosophy 285, at 288-290. This is a question that is not addressed in the article. For the most part, though, Lippke's criticism of this extension is persuasive. See Lippke, supra note 14, at 74-79. ${ }^{86}$ Ashworth, supra note 14, at 243-244; Ferguson, supra note 13; Hamish Stewart, 'The Right to Be Presumed Innocent' (2014) 8 Criminal Law and Philosophy 407; Weigend, supra note 85. The rule of treatment is read into the presumption also by the ECtHR. See Trechsel, supra note 5, at 163-164, 178191. According to art. 6(2) ECHR, the presumption of innocence applies to those 'charged with a criminal offence'. Considering that the term 'charge' is given a broader interpretation in the ECHR system than it is under English and Welsh law (see Trechsel, supra note 5, at 31-33), if the presumption were to contain a rule of treatment, the rule would also apply during the investigative phase. Hence, it would also apply to the benefit of suspects. It seemingly would not apply to those who have already been acquitted of an offence, since these individuals are not 'charged' anymore. But see ibid at 182-189. ${ }^{87}$ See Schwikkard, supra note 14, at 36 and Jackson and Summers, supra note 7, at 205.
} 
access to ${ }^{88}$ If, for instance, we don't want to make friends with cruel and selfish people and we believe that a particular individual is cruel and selfish, we will not make friends with her even if she is actually kind and generous. It follows that demanding that the state authorities treat the suspect/accused as they should treat her if she were actually innocent is making an empty demand. How the authorities should behave vis-à-vis the suspect/accused cannot depend on whether she is actually innocent or not. The authorities have no access to this state of affairs, thus no opportunity to regulate their conduct accordingly. How the authorities should behave depends, instead, on their beliefs on the relevant matters, including on whether the suspect/accused is innocent - which obviously is not to deny that the authorities have a duty to ensure that their beliefs reflect the available evidence on this issue. ${ }^{89}$ However, any belief on whether the suspect/accused is innocent - and on any other relevant fact, for that matter - is compatible with the state of affairs consisting in the actual innocence of the suspect/accused. As a result, the hypothetical fact relied upon by the rule in order to provide a criterion for appropriate conduct - i.e., actual innocence - does not have any constraining effect on the authorities' behaviour.

To properly constrain the behaviour of the authorities towards the suspect/accused we need to formulate the rule so as to refer to the hypothesis that the authorities believe in actual innocence, rather than to the hypothesis of actual innocence itself. Thus, the rule should be expressed as directing the state authorities to treat the suspect/accused as they should treat her if they believed that she is actually innocent. ${ }^{90}$ However, once the rule is spelled out as suggested, it becomes evident that it is an unreasonable rule to impose on the state authorities. Arguably, if the police believed that an individual is actually innocent, they should not investigate her, interview her, arrest her, invite her to take part in an identification procedure, take bodily samples from her, etc. Similarly, if the prosecution believed that an individual is actually innocent, it should not bring charges against her and present a case at trial seeking her conviction. It follows that if the state authorities had to treat the suspect/accused as they should treat her if they believed that she is actually innocent, none of the above actions should ever be performed. Since these actions are vital to the criminal process, under this rule the

\footnotetext{
${ }^{88}$ Of course, this is not to deny that the actuality of the relevant matters can (and probably most often does) influence our beliefs about them.

${ }^{89}$ If the authorities have breached this duty by culpably ignoring any relevant evidence, it is arguable that how they should behave vis-à-vis the suspect/accused depends on the belief that they would have had had they not ignored such evidence.

${ }^{90}$ Another possibility is a rule providing that the state authorities should treat the suspect/accused as they would treat her if they believed that she is actually innocent. How the state authorities would treat the suspect/accused under this hypothetical is an empirical, rather than a normative, question. The answer to this question may depend on variables other than the applicable rules of treatment. These variables may include, for instance, whether the operating officers are honest individuals. Moreover, it is a question that has no univocal answer: similarly situated suspects/accused may be treated differently based on these variables, even if such differential treatment is unwarranted. As a result, this alternative rule does not posit an appropriate, or a stable, criterion for conduct and should be rejected on these grounds.
} 
criminal process would simply become impossible. This is why the rule should be rejected. ${ }^{91}$

\subsection{Treating the suspect/accused as a 'legally' innocent person}

Let's now consider the alternative rule, according to which the state authorities should treat the suspect/accused as legally innocent. Notice that, unlike the rule previously studied, this rule does not consist in hypothesising a state of affairs and in demanding that the state authorities act as they should do if such a state of affairs were true. Indeed, the suspect/accused is by definition legally innocent. She has not been found guilty of the crime charged. Thus, if valid the rule would only apply with regard to someone who is in fact legally innocent.

The precept of the rule is, however, unclear: what does treating someone as legally innocent mean? A possible answer is that it means not treating her as she should be treated if she had been found guilty, i.e., if she were not legally innocent. Reformulated in light of this answer, the rule would provide that the state authorities should not treat the suspect/accused as they should treat her if she had been found guilty of the crime charged. ${ }^{92}$ The problem with a rule so formulated is that there are ways of treating a person that the authorities should endorse both when engaging with someone who has been found guilty and when engaging with someone who has not been found guilty. These include, for instance, respecting the person's dignity and physical integrity. The rule, however, denies this, presenting the treatment required for the legally innocent as alternative to the treatment required for those who have been found guilty.

This problem is avoided by giving a different answer to the question at the start of the previous paragraph: treating the suspect/accused as legally innocent means not treating her in ways that can only be justified in the presence of a finding of guilt, that is, an assertion of guilt that the law regards as concluding the fact finding process. In light of this answer, the rule can be reformulated as stating that the state authorities should not treat the suspect/accused in ways that can only be justified in the presence

\footnotetext{
${ }^{91}$ Would it be sensible to argue that the presumption of innocence requires the particular treatment consisting in declaring actually innocent those who are not found guilty through the proceedings? Without altering dramatically the nature of the criminal process, it wouldn't. The criminal process is not designed to produce claims about actual innocence. The fact that at the end of the process someone is not found guilty does not warrant the claim that she is actually innocent. Since the criminal standard of proof is considerably high, a failure to meet this standard is compatible with the presence of substantial evidence of guilt. Might the presumption of innocence require, instead, that those who are not found guilty through the proceedings be declared legally innocent? A requirement of this kind would be nugatory. Since legal innocence is the state of not having been found guilty through the criminal process, if the defendant is not found guilty, a declaration of legal innocence is in re ipsa.

92 Another possibility would be a rule stating that the state authorities should not treat the suspect/accused as they would treat her if she were found guilty. For a criticism of a rule of this kind cf. supra note 90.
} 
of a finding of guilt. ${ }^{93}$ The most evident implications of this rule are that the state authorities should not refer to the suspect/accused as 'guilty' of the crime charged in any official communication, ${ }^{94}$ and that they should not adopt any measure towards the suspect/accused that amounts to punishment. ${ }^{95}$ This is because, arguably, a finding of guilt is necessary to justify both official assertions of guilt on the part of the authorities and punishment. Instead, measures such as interviewing, arresting, and remanding in custody awaiting trial comply with the rule, since they can be justified by appealing exclusively to considerations other than the presence of a finding of guilt. For instance, an interview may be justified by the need to acquire information about the suspect's involvement in the crime; ${ }^{96}$ an arrest may be justified by the need to prevent the suspect from causing physical injury to another person; ${ }^{97}$ a remand in custody may be justified by the expectation that, if granted bail, the accused would interfere with witnesses or otherwise obstruct the course of justice. ${ }^{98}$

The rule that the state authorities should not treat the suspect/accused in ways that can only be justified in the presence of a finding of guilt conveys most effectively the idea that the suspect/accused should be treated as legally innocent. If legal innocence is the absence of a finding of guilt, treating someone as legally innocent means treating her in any way that can be justified in the absence of a finding of guilt. Whilst this rule is sacrosanct, it is not a component of the presumption of innocence. The rule, instead, is a necessary normative implication - if not an essential defining feature - of the

${ }^{93}$ Thomas Weigend has argued that the presumption of innocence requires that 'any interference with the suspect's rights in the course of the criminal process must be justifiable even if it turns out that the suspect is innocent'. See Weigend, supra note 85 , at 296. The rule considered here is consistent with this requirement. If a finding of guilt is not necessary to justify an interference with the suspect's rights, the interference can be justified to someone who is later acquitted of the crime charged or when the charge against her is later dropped.

${ }^{94}$ The idea that the presumption of innocence protects the suspect/accused from assertions of guilt on the part of the state authorities is well entrenched in the ECtHR case law and endorsed by the scholarship. See Trechsel, supra note 5, at 164, 178-179, Campbell, supra note 14, and Weigend, supra note 85, at 294-295. This idea has also been endorsed in the EU Directive 2016/343 'on the strengthening of certain aspects of the presumption of innocence and of the right to be present at the trial in criminal proceedings'. Article 4.1 of the Directive states: 'Member States shall take the necessary measures to ensure that, for as long as a suspect or an accused person has not been proved guilty according to law, public statements made by public authorities, and judicial decisions, other than those on guilt, do not refer to that person as being guilty.' Notably, whilst the European Union has not yet acceded to the ECHR, art. 48 of the Charter of Fundamental Rights of the European Union states the presumption of innocence in terms that are roughly the same as those of art. 6(2) ECHR, and the latter article is explicitly mentioned in the recital of the Directive just discussed.

${ }^{95}$ There is no attempt here to give a comprehensive account of the measures that are forbidden by the rule in the absence of a finding of guilt. It is possible that these would also include measures other than punishment and official assertions of guilt.

${ }^{96}$ Indeed, section 11.1A of CODE C of the Police and Criminal Evidence Act 1984 defines an interview as 'the questioning of a person regarding their involvement or suspected involvement in a criminal offence or offences'.

${ }^{97}$ Cf. section 24(5)(c)(i) of the Police and Criminal Evidence Act 1984.

${ }^{98}$ Cf. Bail Act 1976, Schedule 1, Part 1, Section 2(1)(c). 
institution of the criminal process itself; to be more precise, of any criminal process that attaches distinctive significance to the finding of guilt. In such a criminal process, only if the defendant is found guilty is it justified to treat her in certain ways. The justification of certain forms of treatment derives precisely from the fact of being found guilty through the process. Now, wouldn't it be contradictory to adopt a criminal process so designed if, even in the absence of a finding of guilt, we allowed the authorities to treat an individual in ways that - according to the design of the process - require such a finding? For this criminal process to be meaningful, the rule at issue here must be part of it.

It was said earlier that for some authors the rule stating that the suspect/accused should be treated as innocent until proven guilty is a logical consequence of the rule allocating the burden of proving guilt to the prosecution. The argument advanced here, instead, is that the relationship of logical implication - if not a truly analytical relationship - is between the institution of the criminal process and the rule of treatment, in the version of this rule currently discussed. Indeed, even in the presence of a hypothetical rule allocating to the accused the burden of proving innocence - a rule which, of course, would conflict with the principle of inertia - it would still be the case that the accused should be treated as legally innocent until a finding of guilt concludes the process. If, absent such a finding, she could be treated in ways that the criminal process justifies only in the presence of it, the normative significance of this process would cease.

The rule that the state authorities should not treat the suspect/accused in ways that can only be justified in the presence of a finding of guilt has solid normative grounding in the institution of any criminal process attaching distinctive significance to the finding of guilt. Therefore, with a criminal process of this kind in place - as it is the case in England and Wales - there is no need for reading this rule into the presumption of innocence. The rule would be justified and operative even if the system did not include the presumption. This view gains support from the consideration that the presumption of innocence - as formulated in art. 6(2)ECHR - presupposes the existence of the criminal process. This confirms that the process is a more fundamental normative entity than the presumption and, therefore, offers a deeper justification to the rule at issue.

To summarise, this section looked at different versions of the rule according to which the suspect/accused should be treated as innocent until found guilty of the crime charged. It discarded the version of the rule employing the concept of actual innocence. Then, it identified a suitable version of the rule employing the concept of legal innocence. It was suggested that the rule, so construed, is not a component of the presumption of innocence; the rule is, instead, a normative implication of the institution of the criminal process. In a last attempt to defend the view that the presumption of innocence has implications for how the suspect/accused should be treated, someone may argue that, at the least, the presumption functions as an aidememoire of sorts. More precisely, the argument would be that the presumption is a reminder for the state authorities - fact finders included, of course - that some 
suspects/accused are indeed innocent, and that, therefore, any decision affecting the development of the process should be taken with due care. There is no doubt that a reminder of this kind would be valuable. However, for the argument to have any descriptive traction it has to be shown that the presumption is understood as such a reminder. This is unlikely to be the case, if anything because neither the name nor the formulation of the presumption seem designed to provide it. From a normative point of view, instead, if we deem the reminder worth giving, we should want to express it in more explicit terms, and to convey it through more specific directives, than the presumption of innocence and its uncertain doctrine can offer.

\section{Concluding remarks}

This article presented a novel theory of the meaning and of the justification of the presumption of innocence. This theory is markedly deflationary. Contrary to the available academic accounts, the common law, and the ECtHR's understanding of the presumption, the theory defended here posits that the presumption consists exclusively in a rule allocating to the prosecution the burden of proving the defendant's criminal responsibility. This rule was justified by appealing to a principle of rationality, the principle of inertia in argumentation. In so doing, the article departed from the traditional justification for allocating the burden of proof to the prosecution, which rests on the value of protecting the innocent from conviction. The view defended here is that this value plays no necessary role in justifying the presumption of innocence.

When reading judicial decisions and academic works, it is not uncommon to encounter statements to the effect that the presumption of innocence includes other prerogatives of the suspect/accused that are part of the fair-trial package, such as the right to silence and the privilege against self-incrimination. Hock Lai Ho's theory of the presumption is a radical example of views of this kind. ${ }^{99} \mathrm{He}$ argued that the presumption of innocence is 'the general right to due process'. This means that the presumption is some sort of catch-all right, encompassing all the rights that are constitutive of a fair trial. More precisely, 'it mandates that the state cannot convict someone of a crime unless and until the prosecution demonstrates her guilt in a process that bears the defining features, including rights and protections, of a fair trial'. ${ }^{100} \mathrm{Ho}^{\prime}$ s conception of the presumption of innocence raises far more questions

\footnotetext{
${ }^{99}$ Another example is the EU Directive 2016/343, supra note 94, whose recital states that ' $[\mathrm{t}]$ he right to remain silent is an important aspect of the presumption of innocence' and that ' $[t]$ he right not to incriminate oneself is also an important aspect of the presumption of innocence' (see, respectively, paras 24 and 25). The ECtHR case law claims that the presumption is 'closely linked' to other fair trial rights, such as the right to an impartial tribunal, the right to be informed promptly of the nature and cause of the accusation, but also the privilege against self-incrimination. See Trechsel, supra note 5, at 164-166, 348 .

${ }^{100}$ See Hock Lai Ho, 'The Presumption of Innocence as a Human Right' in Paul Roberts and Jill Hunter (eds.), Criminal Evidence and Human Rights: Reimagining Common Law Procedural Traditions (Hart 2012),
} 
than it answers. If the presumption encompasses the rights that are constitutive of a fair trial, how is it different from the right to a fair trial? If it is not different from this right, why have both? If the presumption is just the sum of the other fair trial rights, why not retain these rights only and ditch the presumption? If it is more than just the sum of these rights, what is it really? Does the presumption contribute to the justification of these rights? ${ }^{101}$ If so, how does it achieve this? Notably, for the presumption to contribute to the justification of other fair trial rights, it needs to be something other than these rights. But, again, what is this 'something other'? Ho does not address these questions. The plausibility of his account is in doubt until answers are provided.

Recently, Paul Roberts made the interpretive claim that the presumption of innocence is best conceptualised as a mid-level principle of political morality from which a variety of more concrete procedural (and other) doctrinal principles, rules and institutional practices may be derived and rationalised'. ${ }^{102}$ Roberts suggested this conceptualisation towards the end of an article whose primary objective was not to defend a theory of the presumption, but to expose terminological and methodological fallacies characterising the debate concerning its meaning. He did not give a full account of what the principles, rules and practices allegedly justified by the presumption are or of how the presumption justifies them, indicating that this is work for future contributions. The interpretive theory that Roberts plans to develop will likely be markedly different from the theory defended here. Given the account of the meaning and justification of the presumption offered in this article, it will be obvious to the reader that its author is sceptical about the possibility of justifying other fair trial rights on the basis of the presumption. Moreover, whilst Roberts' theory may well turn out to provide a more accurate description of the current law as compared to the account advanced in this article, the main question of interest here is whether it will be more persuasive than such account from a normative point of view. After all, the aim in writing this article was not interpretive, but normative.

Arguing for the proposed deflationary account of the presumption of innocence required considering and discarding several possible components of the presumption that are defended in the literature and in the case law. These components are a standard of proof, a rule imposing on the fact finder a certain cognitive attitude, a rule telling the fact finder to disregard certain evidence, and a rule stating that the authorities should treat the suspect/accused as innocent. Notably, this article argued for the existence of some of these norms, whilst maintaining their independence from the presumption. Because of this, someone may contend that the normative impact of the theory defended here is limited. After all, this article seems to have carried out a

at 266-270. Apparently, Ho's conception of the presumption of innocence has its roots in the jus commune's understanding of the maxim 'innocent until proven guilty'. See Pennington, supra note 7, at 124.

${ }^{101}$ For a criticism of the argument that the presumption of innocence justifies other fair trial rights see Jackson and Summers, supra note 7, at 206-207.

${ }^{102}$ Roberts, supra note 12, at 26. 
simple exercise of rebranding. It considered a set of norms that are generally unified under one name; it then split the set and gave that name to one of those norms only, without compromising the existence of the others. This objection, however, would be unfair. The original set included some norms that have received considerable support in the scholarship, but ultimately have not withstood critical assessment. The article has, therefore, argued that these norms do not exist. Moreover, as regards the norms that have been retained but rehomed outside of the presumption of innocence, the objection would be myopic. Disentangling a norm from the muddled received understanding of the presumption of innocence, and acknowledging its independence, give an opportunity to pin down the norm and to dust the reasons for having it. The norm's visibility and, therefore, its normative impact are likely to be increased as a result of this process. Vice versa, relying on the presumption of innocence as a catchall provision, ready to encompass an ever larger and more amorphous set of norms, creates the risk of concealing and blurring these norms, ultimately weakening the presumption and turning it into nothing more than a rhetorical device. 